J. Perinat. Med. 7 (1979) 78
Determination of fetal lung maturity by $L / S$ ratio, "shake test" and phosphatidylglycerol in amniotic fluid.

Bustos, R.**, Giussi, G.*, Vinacur, J.***, Duhagón, P.***, Magri, R.***, Xercavins, J.***, Caballero, C.*** and Rosas, $\mathrm{R}^{* * * *}$

Latin American Center of Perinatology and Human Development, Pan American Health Organization, World Health Organization, Montevideo, Uruguay

\section{Introduction}

Among the most important needs in the perinatal management of high risk patients, has been to find a valid and reliable test for estimating the degree of pulmonary maturity of the human fetus in utero.

The measurement of amniotic fluid phospholipids has gained widespread popularity in the assessment of fetal lung maturity. Many studies have established beyond doubt that secretion of fetal lung fluid containing surfactant contributes to amniotic fluid composition $[3,5,10,11]$.

Several procedures have been proposed for its evaluation but two of them have been widely acclaimed, the $L / S$ ratio $[4,6,7]$, probably the best method for estimation of fetal pulmonary maturity, and a much simpler method proposed by Clements [2], known as the "shake test" or "foam stability test".

Recently, studies on the perinatal development of lung surfactant in the rat and human $[8,9]$ revealed that, besides lecithin, the lung surfactant complex contains other minor characteristic phospholipids. Phosphatidylglycerol (PG) and phosphatidylinositol have been identified. Although PG function is not clear yet, it seems that its role would be to improve the function of lung surfactant in stabilizing alveoli.

In a previous paper [1] we have reported that the presence of PG in amniotic fluid indicates that fetal lung maturation has been reached and that the newborn will not develop respiratory distress syndrome (RDS), the most serious disease of the neonatal period.

The objective of this study is to compare the L/S ratio, the "shake test", the measurement of PG and precipitated lecithin fraction in amniotic fluid obtained from complicated pregnancies.

\section{Material and methods}

Sixty nine amniotic fluid samples from 53 patients were obtained by transabdominal amniocentesis strictly due to maternal and/or fetal indication, according to the course of pregnancy and the maternal and/or fetal status. All patients had

\footnotetext{
* Head, Biochemical Laboratory of the Latin American Center of Perinatology and Human Development.

** Head Neonatologist of the Latin American Center of Perinatology and Human Development.

*** Fellows of the Pan American Health Organization at the Latin American Center of Perinatology and Human Development.
} 
Tab. I. Distribution of the Pathological Patients

Chronic hypertension. .............. 7

Diabetes B and C . . . . . . . ...... 6

Diabetes D, F, R ................. 6

Rh sensitization. ................. 10

Rh sensitization + hypertension. . . . . . . . 1

Rh sensitization + diabetes. . . . . . . . . 2

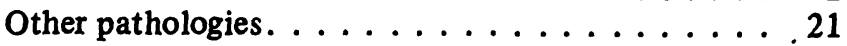

TOT A L

complicated pregnancies, mainly diabetes and $\mathrm{Rh}(-)$ sensitization, as is shown in Tab. I.

Samples contaminated by meconium and/or blood were excluded from our study.

\begin{abstract}
Amniotic fluid samples were $10 \mathrm{ml}$ or more. Phospholipid measurements and "shake test" were performed in every sample. Phospholipids were measured after centrifugation at $3,500 \mathrm{rpm}$ for 10 minutes. Extraction of phospholipids from amniotic fluid supernatant was performed using the procedure described by GLUCK et al [7].

After extraction, acetone precipitation was done and both fractions (acetone-precipitated and acetone-soluble) were plated and run on heated activated thin layers of silica gel $\mathrm{H}$ containing $5 \%$ ammonium sulfate.

The acetone-precipitated fraction was developed on two dimensional thin layer chromatography. The plates were first developed upward s u sing chloroform-methanol-acetic acid $\mathrm{H}_{2} \mathrm{O}(390-150-48-24 \mathrm{v} / \mathrm{v})$ then from right to left with tetrahydrofuran-methylal-methanol-2 $\mathrm{N} \mathrm{NH}_{4} \mathrm{OH} 400$ $-285-78-42 v / v)$.

Between the individual runs the plates were heated to $90^{\circ} \mathrm{C}$ for 5 minutes.

The acetone-soluble fraction was developed on the same plate but only in the first dimension.

After development of the chromatograms the plates were charred at $280^{\circ} \mathrm{C}$ for 10 minutes to visualize the compounds. The comparative densities of acetone-precipitated lecithin (L), sphingomyelin (S), phosphatidylinositol (PI), phosphatidylserin (PS), phosphatidyletanolamine (PE), phosphatidylglycerol (PG) and acetone-soluble lecithin were measured on the thin layer plates by reflectance densitometry.
\end{abstract}

The L/S ratios and percentages of precipitated lecithin were calculated as described previously by GLuCK et al. [6].

The percentages of the phospholipid compounds were correlated in the precipitated fraction by adding the total density readings and calculating the percentage contribution of each fraction.

A modification of the original technique described by CLEMENTS [2] ("shake test") was performed.

Only two dilutions were used: one was $100 \%$ amniotic fluid and in the other, amniotic fluid was diluted to $50 \%$ with saline. It was considered a positive test when a complete ring of bubbles appeared at the meniscus, in both tubes, 15 minutes after shaking; intermediate, when the ring was complete in $100 \%$ amniotic fluid and incomplete or absent in $50 \%$ diluted amniotic fluid; and finally negative when an incomplete or absent ring was found in both tubes.

The statistical analysis was performed by variance analysis and chi square test.

\section{Results}

Fig. 1 shows the characteristic chromatogram obtained in an amniotic fluid sample extracted at 38 weeks of gestation by transabdominal amniocentesis.

The L/S ratio was 3.72, percentage of precipitated lecithin, $56.33 \%$ and the percentages of the different phospholipids in the acetone-precipitated fraction as follows: $\mathrm{S}=13.66 ; \mathrm{L}=50.93 ; \mathrm{PS}=$ 9.93; $\mathrm{PI}=12.42 ; \mathrm{PG}=10.55$ and $\mathrm{PE}=2.48$.

The infant born 3 days after amniocentesis did not develop RDS.

The $\mathrm{L} / \mathrm{S}$ ratio values have been plotted in Fig. 2 according to the results of the "shake test" obtained from the same amniotic fluid sample.

When comparing the $\mathrm{L} / \mathrm{S}$ ratio values, a statistically significant difference was found between the negative group and the group of the intermediate and positive cases. No difference was found between the last two groups.

An L/S ratio of 2.0 is taken as the limit of lung maturity. In the negative "shake test" group, 9 of the 30 samples showed $L / S$ values equal or higher than 2.0. Thus $30 \%$ of this group were "false negatives". On the other hand, in the intermediate and positive "shake test" groups, all the values of L/S ratio were equal or higher than 2.0 (except one sample for each group).

The percentages of PG were correlated with the values of the "shake test" and the results are shown in Fig. 3. The average value of PG in amniotic fluid is higher in the intermediate and positive groups, than in the negative one. PG was not found in almost any case of the negative "shake test". PG was absent in $43 \%$ of the inter- 


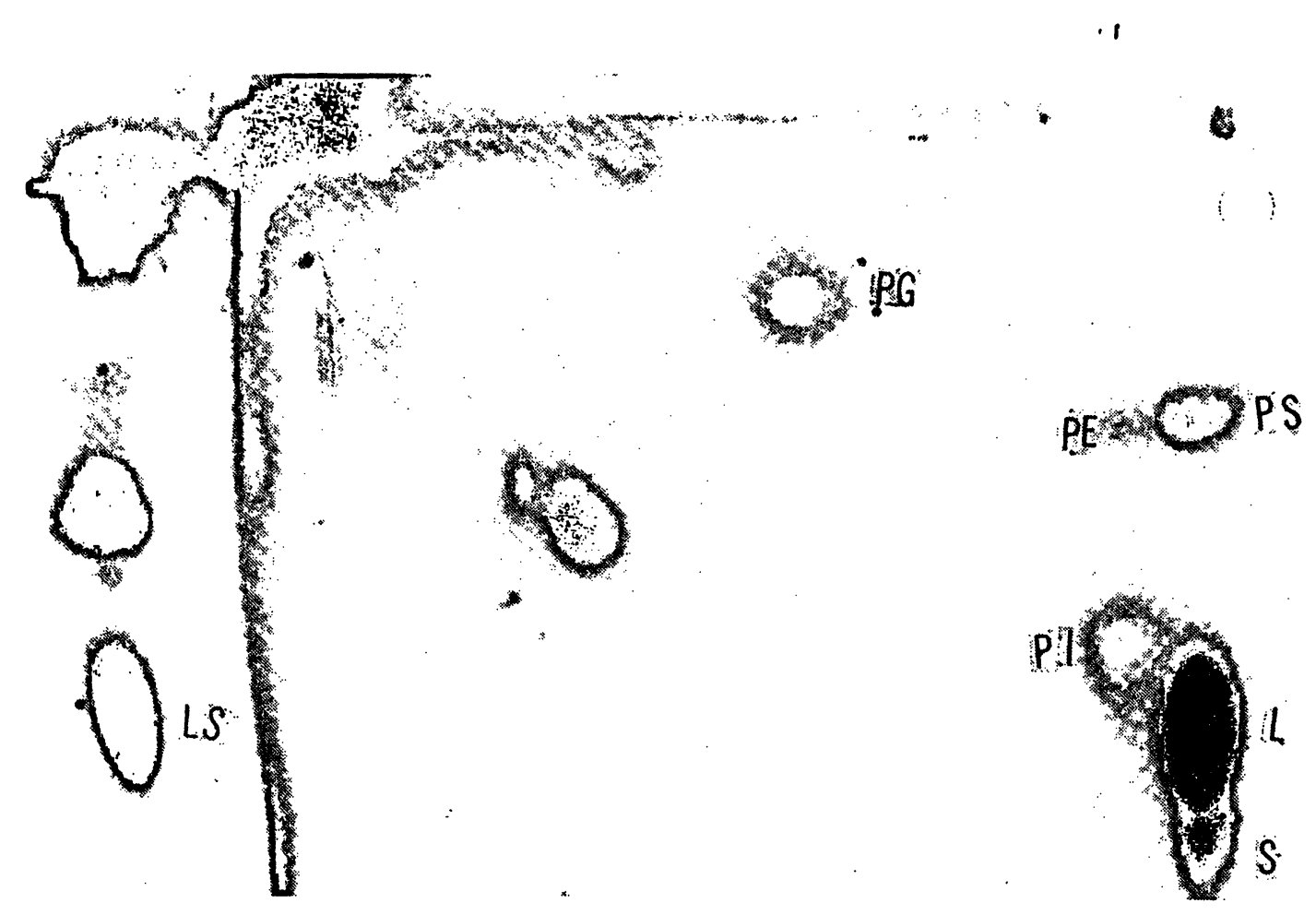

Fig. 1. The $\mathrm{L} / \mathrm{S}$ ratio, the percentage of acetoneprecipitated fraction of lecithin $(\mathrm{L})$ and the different phospholipids are shown in this chromatogram obtained in a sample of amniotic fluid obtained at term pregnancy.

$\mathrm{S}=$ sphingomyelin; $\mathrm{PI}=$ phosphatid ylinositol; $\mathrm{PS}=$ phosphatidylserin; $\mathrm{PE}=$ phosphatidyletanolamine; $\mathrm{PG}=$ phosphatidylglycerol; LS = acetone-soluble lecithin.

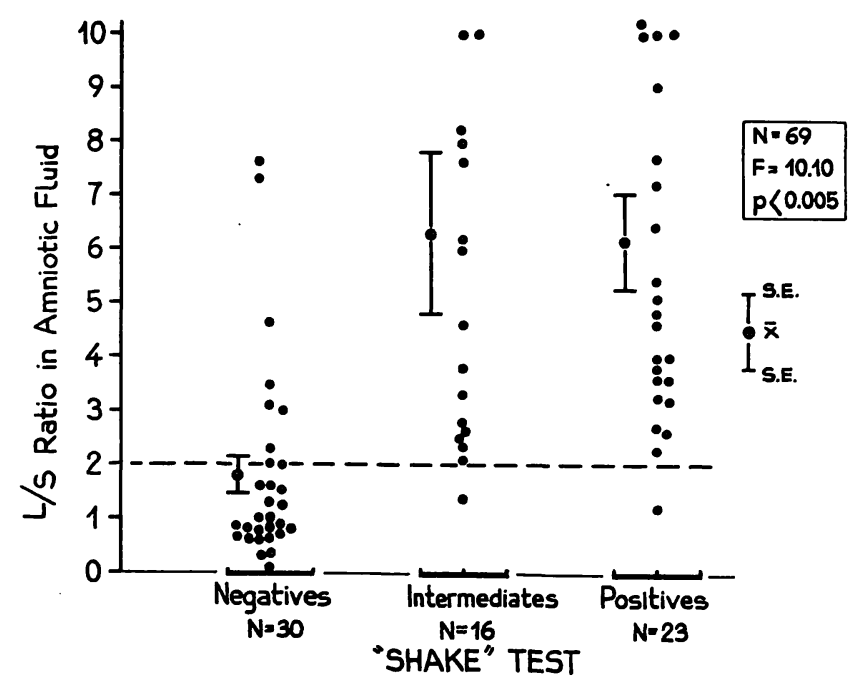

Fig. 2. The $\mathrm{L} / \mathrm{S}$ ratio values were lower for the negative group than for the intermediate and positive cases. In the negative "shake test" group a high percentage of false negative samples (30\%) was found.

mediate group and in $27 \%$ of the positive group. The variance analysis showed a statistically significant difference between the three groups $(\mathrm{p}<$ 0.005).

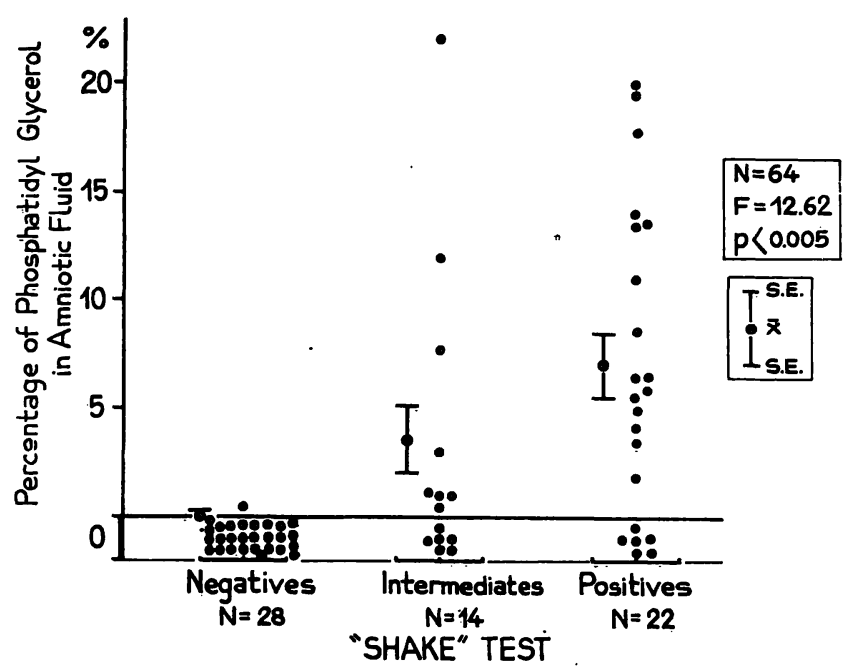

Fig. 3. The percentage of $P G$ is higher in the intermediate and positive groups than in the negative one. PG was not found in almost any case of the negative group.

In Fig. 4 are shown the results obtained from the study of the values of $P G$ and $L / S$ ratio. The amniotic fluid samples were divided into two groups, according to their L/S ratio; one group was 


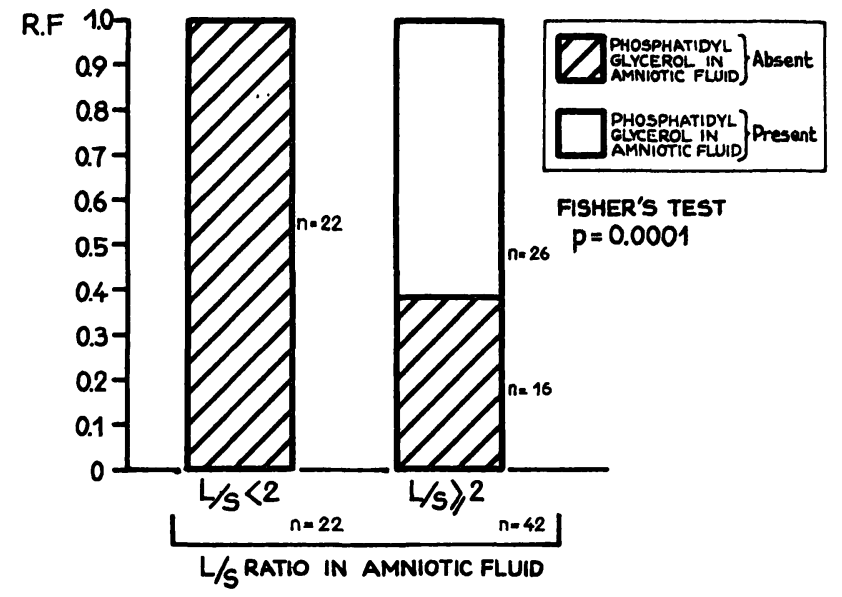

Fig. 4. No PG was found in the samples with an $\mathrm{L} / \mathrm{S}$ ratio less than 2.0 , as well as in $38 \%$ of those with an $\mathrm{L} / \mathrm{S}$ ratio higher than 2.0.

greater or equal to 2.0, and the other less than 2.0. PG was under detection limit in the samples with an $\mathrm{L} / \mathrm{S}$ ratio less than 2.0 , as well as in $38 \%$ of those with an $\mathrm{L} / \mathrm{S}$ ratio higher than 2.0 . The FISHER test showed a significant statistical difference $(p=0.0001)$. Thus the presence of PG is associated with an $L / S$ ratio equal or higher than 2.0.

In Fig. 5, the percentage of precipitated lecithin fraction in amniotic fluid was correlated with the $\mathrm{L} / \mathrm{S}$ ratio. The amniotic fluid samples were divided into two groups according to their percentage of precipitable lecithin; in one group it was equal or

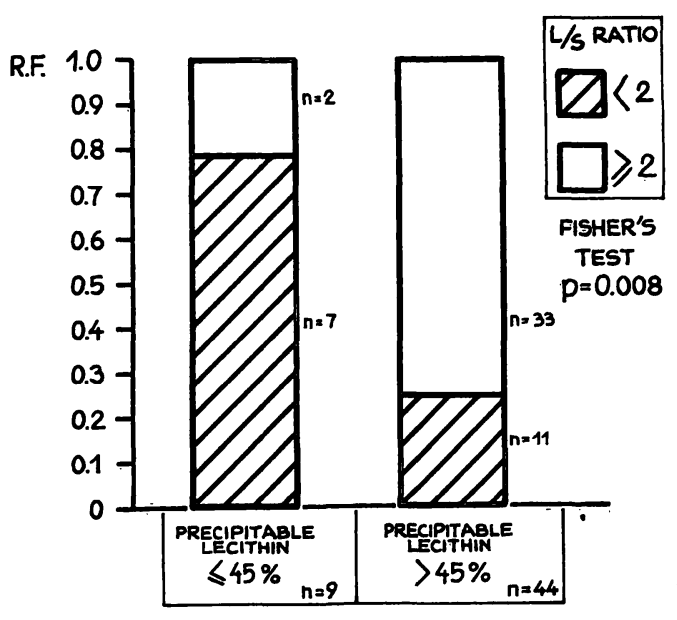

Fig. 5. When precipitable lecithin was equal or less than $45 \%$ of total lecithin, $78 \%$ of the samples had an L/S ratio lower than 2.0 . Only $25 \%$ of the samples with precipitable lecithin greater than $45 \%$ had an $\mathrm{L} / \mathrm{S}$ ratio lower than 2.0.

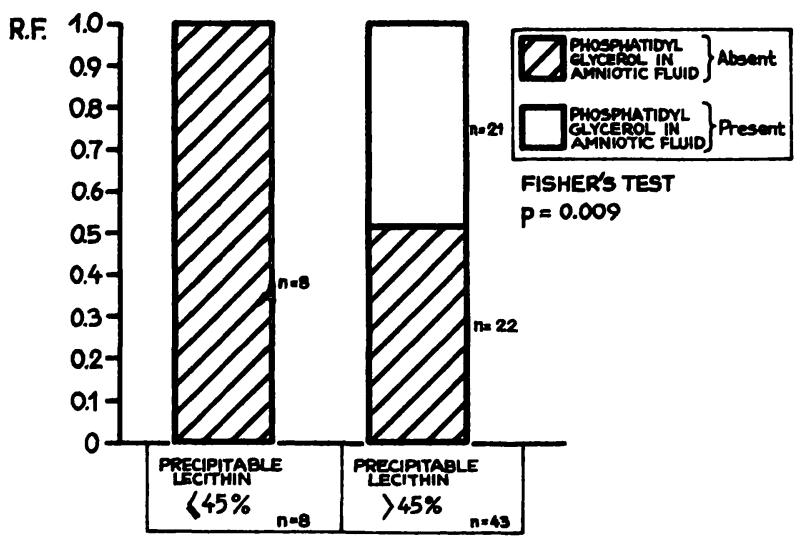

Fig. 6. No PG was found in the samples with precipitable lecithin equal or less than $45 \%$. PG was present in $49 \%$ of the samples with precipitable lecithin higher than $45 \%$.

less than $45 \%$, and in the other more than $45 \%$.

When the precipitable lecithin was equal or less than $45 \%$ of total lecithin, $78 \%$ of the samples had an $\mathrm{L} / \mathrm{S}$ ratio lower than 2.0. On the other hand, only $25 \%$ of the samples with precipitable lecithin greater than $45 \%$ had an L/S ratio lower than 2.0. According to the Fisher test, the difference was statistically significant $(p=0.008)$.

In Fig. 6 are shown the results obtained from the study of values of PG with precipitable lecithin. The samples were divided into the same two groups according to precipitable lecithin values. No PG was found in the samples with precipitable lecithin equal or less than $45 \%$. PG was absent in $51 \%$ of the samples with precipitable lecithin greater than 45\%. The Fisher test showed a statistically significant difference $(p=0.009)$.

\section{Comments}

The increasing demand for the measurement of fetal pulmonary surfactant in amniotic fluid, to predict the likelihood of neonatal respiratory distress led us to evaluate more simple procedures to measure amniotic fluid surface tension as a possible screening test.

Our results were similar to that of a previous publication [12] confirming that the "shake test" is a good screening method, since a positive result practically indicates maturity of the fetal lung. However, the high percentage $(30 \%)$ of false negatives (samples with negative "shake test" and L/S ratio greater than 2.0 ) indicates that the "shake 
test" may not be safe, specially in high risk pregnancies where a clinical confirmation should be reached soonest.

We would, therefore, suggest that in such cases the L/S ratio must also be measured, to enable a more precise prediction of the risk of respiratory distress.

Another aspect is that all $\mathrm{L} / \mathrm{S}$ ratio values obtained in the intermediate group (except for one sample) were higher than 2.0. Therefore, when an intermediate "shake test" value is obtained, we may assume, for our population, that the fetus has reached the lung maturity expressed by an L/S ratio higher than 2.0 .

According to our previous publication [1], the presence of PG in amniotic fluid allows to predict that the newborn will not develop a respiratory distress syndrome.

In our results the absence of PG was strongly associated with a negative "shake test". However, the reverse situation was not observed, as several amniotic fluid samples with positive "shake test" did not show presence of PG. Nevertheless, we may conclude that the presence of $P G$ in amniotic fluid is a good indicator of fetal lung maturation, since when present, $\mathrm{L} / \mathrm{S}$ ratio was equal or greater than 2.0. However, its absence does not indicate the opposite. This statement is supported by the results presented in Fig. 4. PG was not found in any sample with $\mathrm{L} / \mathrm{S}$ ratio less than 2.0 , and neither in $38 \%$ of those with $\mathrm{L} / \mathrm{S}$ ratio higher than 2.0 .

In a general way, we can conclude from our results, that the "shake test" may be used as a good screening test, but its value is limited when used exclusively.

When a negative "shake test" is obtained, a densitometer determination of $L / S$ ratio and PG should be done, in order to obtain a more reliable diagnosis of fetal lung maturity.

\section{Summary}

The measurement of amniotic fluid phospholipids has gained widespread popularity in the assessment of fetal lung maturity.

Several procedures have been proposed for its evaluation but two of them have been widely acclaimed, the L/S ratio, probably the best method for estimation of fetal pulmonary maturity, and a much simpler method proposed by CLEMENTS, known as the "shake test" or "foam stability test".

Recent studies revealed that, besides lecithin, the lung surfactant complex contains other minor characteristic phospholipids. Phosphatidylglycerol (PG) and phosphatidylinositol have been identified and their role would be to improve the function of lung surfactant. The objective of this study is to compare the $\mathrm{L} / \mathrm{S}$ ratio, the "shake test", the measurement of PG and precipitated lecithin fraction in amniotic fluid obtained from complicated pregnancies.

Sixty nine amniotic fluid samples from 53 patients were obtained by transabdominal amniocentesis according to the course of pregnancy and the maternal and/or fetal status.

Phospholipid measurements and "shake test" were performed in every sample. $L / S$ ratio was measured from amniotic fluid supernatant using the procedure described by GLUCK et al.

The identification of minor phospholipids (PI and PG) was done by two dimensional thin layer chromatography (Fig. 1).
A modification of the original technique described by CLEMENTS ("shake test") was performed. Only two dilutions were used: one was $100 \%$ amniotic fluid and in the other, amniotic fluid was diluted to $50 \%$ with saline. When comparing the $\mathrm{L} / \mathrm{S}$ ratio values, a statistically significant difference was found between the negative "shake test" group and the intermediate and positive tests. No difference was found between these last two groups.

When an $\mathrm{L} / \mathrm{S}$ ratio of $\mathbf{2 . 0}$ was taken as the limit of lung maturity, $30 \%$ of the results were false negative "shake tests" (Fig. 2).

These results were similar to that of a previous publication confirming that the "shake test" is a good screening method, since a positive result practically indicates maturity of the fetal lung. However, the high percentage (30\%) of false negatives indicates that the "shake test" may not be safe.

The percentages of PG were correlated with the values of the "shake test" and L/S ratio and it was found that PG was almost always absent in the negative "shake test" and always absent when $\mathrm{L} / \mathrm{S}$ ratio is lower than 2.0 , showing that lung maturity has not yet been reached (Fig. 4).

We can conclude from our results, that the "shake test" may be used as screening test, although its value is limited when used exclusively. When a negative "shake test" is obtained, determination of L/S ratio and PG should be done.

Keywords: Amniotic fluid, fetal lung maturity, lecithin, phosphatidylglycerol, phospholipids, "shake test". 


\section{Zusammenfassung}

Bestimmung der fetalen Lungenreife durch L/S-Ratio, Schüttelprobe und Phosphatidylglycerin-Bestimmung im Fruchtwasser.

Das Messen der Phospholipide im Fruchtwasser hat weltweite Popularität bei der Beurteilung der fetalen Lungenreife gewonnen.

Mehrere Verfahren wurden für die wissenschaftliche Auswertung vorgeschlagen, aber $\mathbf{z w e i}$ von diesen wurden weithin akzeptiert: die L/S-Ratio, wahrscheinlich die beste Methode zur Bestimmung der fetalen Lungenreife, und eine viel einfachere, die von CLEMENTS vorgeschlagene und unter der Bezeichnung "Schüttelprobe" bekannt gewordene Methode.

Neuere Untersuchungen bestätigen, daß der Surfactant außer Lezithin noch andere, weniger wichtige charakteristische Phospholipide enthält. Phosphatidylglycerin (PG) und Phosphatidylinositol (PI) sind nachgewiesen worden und ihre Aufgabe ist die Verbesserung der Funktion des Surfactants.

Die Aufgabe dieser Studie ist ${ }^{\circ}$ es, die L/S-Ratio, die Schüttelprobe, die Messung von PG und die präzipitierte Lezithin-Fraktion im Fruchtwasser bei Risiko-Schwangerschaften zu vergleichen. 69 Fruchtwasserproben wurden von 53 Patientinnen durch transabdominale Amniozentese entnommen und entsprechend dem Verlauf der Schwangerschaft und dem mütterlichen und/oder fetalen Status geordnet.

Phospholipid-Messungen und Schüttelprobe wurden bei jeder Probe vorgenommen. L/S-Ratio wurde vom Fruchtwasser nach Fällen gemessen, so wie das Verfahren bei GLUCK et al. beschrieben ist. Die weniger wichtigen Phospholipide (PI und PG) wurden durch zweidimensio- nale Dünnschichtchromatographie identifiziert (Fig. 1). Eine Abwandlung der von CLEMENTS beschriebenen Originaltechnik (Schüttelprobe) wurde ausgefuhrt. Allein zwei Verdünnungen wurden benutzt: Eine war $100 \%$ iges Fruchtwasser und bei der anderen wurde das Fruchtwasser mit $50 \%$ Kochsalz verdünnt.

Beim Vergleich der L/S-Ratio-Werte mit den Ergebnissen der Schüttelprobe findet man eine statistisch signifikante Differenz zwischen der negativen SchüttelprobeGruppe und den dazwischen liegenden und positiven Tests. Zwischen diesen beiden letzten Gruppen wurde keine Differenz gefunden. Wenn eine L/S-Ratio 2.0 als Limit der Lungenreife angenommen wird, dann wären 30\% der Schüttelproben falsch negativ (Fig. 2).

Diese Ergebnisse ähneln denen einer vorhergehenden Veröffentlichung, nach der die Schüttelprobe eine gute Untersuchungsmethode ist, da ein positives Ergebnis die Reife der fetalen Lunge anzeigt. Der hohe Prozentsatz (30\%) von falsch negativen Befunden weist darauf hin, daß die Schüttelprobe nicht als sicher zu bezeichnen ist.

Korreliert man die PG-Gehalte mit den Ergebnissen der Schüttelprobe und der L/S-Ratio-Bestimmung, zeigt sich, daß PG in den negativen Schüttelproben meist fehlte. Es fehlte immer, wenn die L/S-Ratio niedriger als 2.0, d.h. die Lungenreife noch nicht erreicht war (Fig. 4).

Wir können aus unseren Untersuchungen schließen, daß die Schüttelprobe als Screening Test verwandt werden kann, obgleich ihr Wert begrenzt ist, wenn sie ausschließlich Verwendung findet. Wenn eine negative Schüttelprobe vorliegt, sollte die Bestimmung der L/S-Ratio und der PG vorgenommen werden.

Schlüsselwörter: Fruchtwasser, Lezithin, Lungenreife (fetale), Phosphatidylglycerin, Phospholipide, Schüttelprobe.

\section{Résumé}

Détermination de la Maturité pulmonaire foetale par le L/S ratio, le "shake test" et les glycerophospholipides du liquide amniotique

La mesure des phospholipides du liquide amniotique reprend de l'importance dans l'évaluation de la maturité pulmonaire foetale.

Plusieurs méthodes ont été proposées, mais deux d'entre elles ont connu un succés particulier: d'une part, le $L / S$ ratio qui paraît être la meilleure méthode d'évaluation de la maturité pulmonaire foetale, et, d'autre part, le procédé plus simple élaboré par CLEMENTS sous le nom de «shake test» ou «foam stability test».

Des études récentes ont montré qu'outre la lécithine, le complexe surfactant pulmonaire contient aussi d'autres phospholipides moins spécifiques. Les glycero-phosphatidyles (PG) et les inosito-phosphatydiles (PI) ont pu être identifiés ainsi que leur fonction d'agent de stabilisation du surfactant pulmonaire.

Notre étude a pour objet la comparaison du L/S ratio, du "shake test", des mesures de PG et de la fraction de lécithine précipitée dans le liquide amniotique de grossesses compliquées. 69 échantillons de liquide amniotique de 53 parturientes ont été prélevés par amniocentèse transabdominale compte tenu du déroulement de la grossesse et de l'état maternel et/ou foetal.

Des mesures de phospholipides et le «shake test» ont été effectués sur chaque échantillon. On a mesuré le $\mathrm{L} / \mathrm{S}$ ratio du liquide amniotique surnatant en utilisant la méthode décrite par GLUCK et al.

L'identification des phospholipides mineurs (PI et PG) a été réalisée par chromatographie de couche mince à deux dimensions (fig. 1).

La technique d'origine décrite par CLEMENTS («shake test») a été modifiée avec utilisation de deux dilutions seulement: une de $100 \%$ de liquide amniotique, l'autre étant une dilution saline à $50 \%$ du liquide amniotique.

$\mathrm{La}$ comparaison des valeurs du $\mathrm{L} / \mathrm{S}$ ratio a montré une différence statistique importante entre le groupe de «shake test" négatif et les tests intermédiaires et positifs. Par contre, aucune différence n'a été relevée entre ces deux derniers groupes.

Le L/S ratio de 2.0 ayant été considéré comme la limite de la maturité pulmonaire, $30 \%$ des résultats sont apparus comme des faux «shake tests» négatifs (fig. 2).

Ces résultats ont été similaires à ceux d'une publication antérieure où il était confirmé que le «shake test» est 
une bonne méthode collective, un résultat positif constituant pratiquement l'indication de la maturité pulmonaire foetale. Néanmoins, le pourcentage élevé (30\%) des faux négatifs donne à supposer que le «shake test» n'est pas absolument sûr.

Les pourcentages de PG ont été confrontés avec les valeurs du «shake test» et du $\mathrm{L} / \mathrm{S}$ ratio avec la conclusion que le PG est presque toujours absent dans le «shake test» négatif et toujours absent lorsque le $\mathrm{L} / \mathrm{S}$ ratio est inférieur à 2.0, montrant ainsi que la maturité pulmonaire n'était pas encore atteinte dans cøs cas-là (fig. 4).

A la suite de ces résultats, nous pouvons conclure que le "shake test» peut être utilisé comme test collectif bien que sa valeur soit limitée quand il n'est pas doublé d'autres tests. En présence d'un «shake test» négatif, il est utile de procéder à une détermination du PG et du L/S ratio.

Mots-clés: glycero-phosphatydiles, maturité pulmonaire foetale, liquide amniotique, lécithine, phospholipides, «shake test».

Acknowledgement: We acknowledge with thanks the cooperation of Mrs. MARTA SCORZA for the thin layer chromatography technique.

Bibliography

[1] BUSTOS, R., M. V. KULOVICH, L. GLUCK: Significance of phosphatidylinositol and phosphatidylglycerol in amniotic fluid of complicated pregnancies. Clin. Res. 24 (1976) 191 A

[2] Clements, J. A., A. C. G. PlatzKeR, D. F. TIERNEY, C. J. HOBEL, R. K. CREASI, A. J. MARGOLLIS, D. W. THIBAULT, W. H. TOOLEY, W. OH: Assessment of the risk of the respiratory distress syndrome by a rapid test for surfactant in amniotic fluid. New Engl. J. Med. 286 (1972) 1077

[3] ClementS, J. A.: Composition and properties of pulmonary surfactant. In: VILLEE, C. A., D. B. VILLEE, J. ZUCKERMAN: Respiratory distress syndrome. Academic Press, New York, 1973

[4] GLUCK, L., M. V. KULOVICH, R. C. BORER, (Jr.), P. H. BRENNER, G. G. ANDERSON, W. N. SPELLACY: Diagnosis of the respiratory distress syndrome by amniocentesis. Amer. J. Obstet. Gynec. 109 (1971) 440

[5] GLUCK, L., R. A. CHEZ, M. V. KUloviCH, D. C. HUTCHINSON, W. H. NIEMANN: Comparison of phospholipid indicators of fetal lung maturity in the amniotic fluid of the monkey (Macaca mulatta) and baboon (Papio papio). Amer. J. Obstet. Gynec. 120 (1974) 524

[6] GLUCK, L., M. V. KULOVICH, R. C. BORER (Jr.), W. N. KEIDEL: The interpretation and significance of the lecithin/sphingomyelin ratio in amniotic fluid. Amer. J. Obstet. Gynec. 120 (1974) 142
[7] GLUCK, L., M. V. KULOVICH, R. C. BORER (Jr.): Estimates of fetal lung maturity. Clinics in Perinatology 1 (1974) 125

[8] HALLMAN, M., L. GLUCK: Phosphatidylglycerol in lung surfactant: Its synthesis in rat lung microsomes. Biochem. biophys. Res. Commun. 60 (1974) 1

[9] HALLMAN, M., M. KULOVICH, E. KIKPATRICK, R. SUGARMAN, L. GLUCK: Phosphatidylinositol and phosphatidylglycerol in amniotic fluid: Indices of lung maturity. Amer. J. Obstet. Gynec. 125 (1976) 613

[10] NOVY, M. J., O. W. PORTMAN, M. BELL: Evidence for pulmonary and other sources of amniotic fluid phospholipids in the Rhesus monkey. In: VILLEE, C. A., D. B. VILLEE, J. ZUCKERMAN: Respiratory distress syndrome. Academic Press, New York 1973

[11] REYNOLDS, W. A., R. M. PITKIN, L. J. FILER (Jr.): Proceedings, Medical Perinatology, 1972. Proceedings of the Third Conference on Experimental Medicine and Surgery in Primates, Lyon 1972, S. Karger, Basel, 1972

[12] SPROULE, W. B., M.E. GREENE, C.R.WHIT FIELD: Amniotic fluid bubble stability test as a screening procedure for predicting the risk of neonatal respiratory distress. Amer. J. Obstet. Gynec. 119 (1974) 653

Received May 18, 1978. Accepted August 9, 1978.

Dr. Raúl Bụstos

Centro Latinoamericano de Perinatología

y Desarrollo Humano

Casilla de Correo 627

Montevideo, Uruguay 


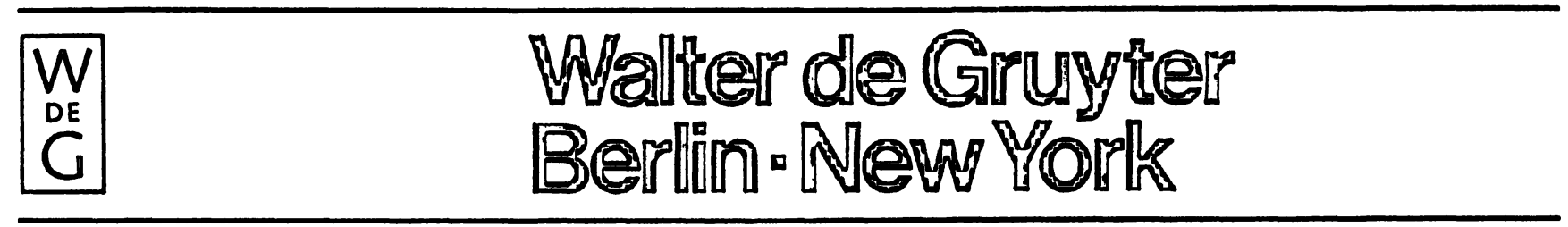

\section{A. W. Norman et al. (Editors)}

\title{
Vitamin D
}

\section{Biochemical, Chemical and Clinical Aspects Related to Calcium Metabolism}

\author{
Proceedings of the Third Workshop on Vitamin D, Asllomar, Pacific \\ Grove, California, USA, January 1977.
}

Editors: A. W. Norman, K. Schaefer, J. W. Coburn, H. F. DeLuca, D. Fraser, H. G. Grigoleit, D. von Herrath.

1977. $17,0 \mathrm{~cm} \times 24,0 \mathrm{~cm}$. XL, 973 pages. With numerous figures. Bound DM 175,-; $\$ 87.50$

ISBN 3110069180

\section{Vitamin D and Problems Related to Uremic Bone Disease}

A. W. Norman et al. (Editors)
Proceedings of the Second Workshop on Vitamin D, Wiesbaden, West Germany, October 1974.

Editors: A. W. Norman, K. Schaefer, H. G. Grigoleit, D. von Herrath, E. Ritz.

1975. $17,0 \mathrm{~cm} \times 24,0 \mathrm{~cm}$. XXVI, 779 pages.

With numerous illustrations. Bound DM 165,-; $\$ 82.50$

ISBN 3110057751

These books give a survey of present knowledge and research on numerous facets of calcium and bone metabolism. The problems are presented and dicussed from various standpoints (biochemists, clinicians, osteologists). In addition, a report is made on the latest vitamin $D$ research. The main point of these proceedings is the timeliness of each single contribution as well as the very informative summary of current problems of calcium metabolism, especially in reference to clinical aspects and perspectives. These books are of interest to those engaged in calcium metabolism, vitamin D research, problems of chronic kidney insufficiency, general osteologic problems, and endocrinology.

Prices are subject to change

For USA and Canada: Please send all orders to Walter de Gruyter Inc., 3 Westchester Plaza, Elmsford, New York 10523. Tel. (914) 592-5890 


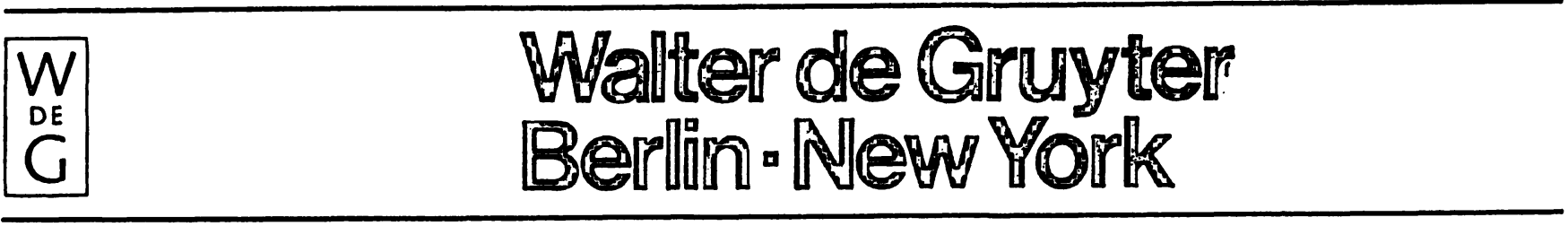

Eduard Gitsch

(Hrsg.)

H. Götz

E. S. Bücherl

(Editors)

\section{Radioisotope in Geburtshilfe und Gynäkologie}

Verfaßt von E. Gitsch, H. Janisch, S. Leodolter, W. H. F. Schnelder, J. Spona. Mit einem Geleitwort von Karl zum Winkel. Mit deutschen und englischen Zusammenfassungen. With summaries in German and English.

$17,0 \mathrm{~cm} \times 24,0 \mathrm{~cm} . \mathrm{XX}, 544$ Seiten. Mit 139 Abbildungen. 1977. Gebunden DM 235,- ISBN $311004532 X$

Darstellung diagnostischer und therapeutischer nuklearmedizinischer Methoden, die für die moderne Geburtshilfe und Gynäkologie von Bedeutung sind.

Schwerpunkt: Die in der I. Universitäts-Frauenklinik Wien entwickelte Radioisotopen-Radikaloperation des Gebärmutterhalskrebses.

Aus dem Inhalt ferner: Grundlagen der Nuklearmedizin. Geburtshilflicher Teil (Nephrologie, Computer-Nephrographie; Venenthrombosen; Plazenta) Gynäkologischer Teil (Gynäkologische Lymphologie; Tumordiagnostik und Tumorimmunologie; die gynäko-urologische Radioisotopenoperation). Radioimmunologische Hormondiagnostik (der Radioimmunoassay; Pathologie des Zyklus; endokrin-bedingte pathologische Gravidität; endokrin-bedingte Sterilität; hormonale Kontrazeption; hormonbildende Tumore).

\section{Applied Tumor Immunology}

Methods of Recognizing Phenomena Specific to Tumors Proceedings of the First International Symposium Berlin, November 1972

1975. $17,0 \mathrm{~cm} \times 24,0 \mathrm{~cm}$. XII, 355 pages. Bound DM 125,-; $\$ 62.50$ ISBN 3110042428

Contents: Methods for detection of tumor-specific sensitized lymphocytes - Methods for detection of molecular antibodies against tumor proteins - Methods for detection of tumor cell surface antigens Methods for detection of non tumor antigens and fetal proteins Methods for detection of proteins excreted by tumor cells - Some clinical aspects. 